\title{
Evaluasi Hidrolis Jaringan Distribusi Air Minum Sistem Beber PDAM Tirta Jati Kabupaten Cirebon
}

\section{Hydraulic Evaluation of Beber System's Water Distribution Networks of PDAM Tirta Jati Cirebon Regency}

\author{
MAHARANI ANASTASYA SUKMAWARDANI ${ }^{1}$, MOHAMAD RANGGA SURURI ${ }^{1 *}$, ARIEF DHANY \\ SUTADIAN ${ }^{2}$ \\ ${ }^{1}$ Program Studi Teknik Lingkungan, Fakultas Teknik Sipil dan Perencanaan, Institut Teknologi Nasional, Bandung \\ ${ }^{2}$ Badan Penelitian dan Pengembangan Daerah (BP2D) Jawa Barat \\ Email korespondensi: rangga@itenas.ac.id
}

\begin{abstract}
Water loss is a severe problem in the drinking water supply system as it disrupts the continuity of the drinking water supply. The largest proportion of water losses is usually found in distribution systems. This study was located in the Beber water supply system, PDAM Tirta Jati Cirebon Regency. The study aimed to evaluate the hydraulic condition and give improvement recommendations for the Beber piping network system distribution. This research performed the International Water Association (IWA) water balance concept through water production and water usage data. Furthermore, the hydraulic condition is evaluated using water usage, ground-level elevation, water usage pattern, and the existing distribution network's technical data. The evaluation was conducted by simulation using EPANET 2.0 from the Environmental Protection Agency (EPA), which then compared to the design criteria listed in Permen PUPR No. 27 2016. The results show a 44.38\% percentage of water loss due to a pipe leak. Simulation results showed a segment of pipe having velocity less than $0.3 \mathrm{~m} / \mathrm{s}(43.31 \%)$, and all nodes had pressure below 12.4 MPa. The simulation results also showed some nodes had pressure greater than $100 \mathrm{mKa}$ and exceeded the HDPE SDR 17 pipe's maximum capacity. This condition causes many pipe leaks that occur in the system, so it is recommended to install a Pressure Reducing Valve (PRV) and change of pipe diameter. The study also suggests establishing a District Meter Area (DMA) to detect pipe leak points.
\end{abstract}

Keywords: water loss, distribution network, pipe leakage, DMA, EPANET 2.0.

\begin{abstract}
ABSTRAK
Kehilangan air merupakan masalah serius dalam Sistem Penyediaan Air Minum (SPAM) karena mengganggu kontinuitas penyediaan air minum. Kehilangan air terbesar biasanya ditemui pada sistem distribusi termasuk pada SPAM Beber milik PDAM Tirta Jati Kabupaten Cirebon. Tujuan studi ini adalah untuk melakukan evaluasi hidrolis dan memberikan rekomendasi perbaikan pada sistem jaringan perpipaan distribusi SPAM Beber. Evaluasi dilakukan dengan konsep neraca air sesuai standar International Water Association (IWA) dengan menggunakan data debit produksi dan pemakaian air. Selanjutnya dilakukan evaluasi hidrolis jaringan menggunakan data pemakaian air, elevasi muka tanah, pola pemakaian air, serta data teknis jaringan distribusi eksisting. Evaluasi dilakukan dengan membuat simulasi hidrolis menggunakan software EPANET 2.0 dari Environmental Protection Agency (EPA) yang kemudian dibandingkan dengan kriteria desain yang tercantum dalam Permen PUPR No. 27 Tahun 2016. Hasil evaluasi menunjukkan persentase kehilangan air mencapai $44,38 \%$ akibat kebocoran pipa. Hasil simulasi hidrolis menunjukkan, terdapat segmen pipa yang memiliki kecepatan aliran kurang dari 0,3 $\mathrm{m} /$ detik $(43,31 \%)$ dan seluruh nodes memiliki sisa tekan dibawah 12,4 MPa. Hasil simulasi juga menunjukkan terdapat nodes yang memiliki sisa tekan sebesar $100 \mathrm{mKa}$ dan melebihi kapasitas maksimum dari pipa HDPE SDR 17. Kondisi ini menjadi salah satu penyebab tingginya angka kebocoran pipa yang terjadi pada sistem, sehingga perlu dilakukan perbaikan dengan pemasangan PRV dan pergantian diameter pipa. Penataan District Meter Area (DMA) juga dapat dilakukan sebagai solusi untuk mempermudah pendeteksian titik kebocoran pipa.
\end{abstract}

Kata Kunci : kehilangan air, jaringan distribusi, kebocoran pipa, DMA, EPANET 2.0. 


\section{PENDAHULUAN}

\subsection{Latar Belakang}

Sistem Penyediaan Air Minum (SPAM) merupakan sistem yang berfungsi untuk menyediakan air minum dari sumber hingga ke daerah pelayanan(1). Jaringan perpipaan distribusi air minum menjadi salah satu infrastruktur penting untuk memenuhi kebutuhan air minum masyarakat perkotaan(2). PDAM Tirta Jati memiliki kapasitas terpasang sebesar 673 liter/detik dan melayani 280.164 jiwa di Kabupaten Cirebon yang tersebar di 40 Kecamatan dengan total Sambungan Langganan (SL) sebesar 38.074. Pada tahun 2019, PDAM Tirta Jati memiliki 9 SPAM, salah satunya adalah Sistem Beber yang melayani Kecamatan Beber dan Kecamatan Talun. Sistem Beber menggunakan air yang bersumber dari mata air Linggarjati dengan kapasitas terpasang sebesar 75 liter/detik $^{(3)}$.

PDAM Tirta Jati memiliki kapasitas distribusi mencapai $942.134 \mathrm{~m}^{3}$ pada bulan Juli dengan volume air yang terjual sebanyak $657.089 \mathrm{~m}^{3}$, total kehilangan air pada bulan Juli 2019 sebesar $285.045 \mathrm{~m}^{3}$ atau sebesar $30,26 \%{ }^{(4)}$. Pada bulan tersebut, Sistem Beber memproduksi air sebesar $161.672 \mathrm{~m}^{3} \quad(100 \%$ dari keseluruhan produksi SPAM PDAM Tirta Jati) dengan total air yang terjual hanya sebesar $89.738 \mathrm{~m}^{3(4)}$. Fakta tersebut menunjukkan adanya air yang hilang akibat kebocoran pada pipa distribusi Sistem Beber dan kondisi ini memberikan dampak kerugian finansial kepada perusahaan air minum(5).

Permasalahan tersebut harus diperhatikan karena Peraturan Pemerintah Republik Indonesia Nomor 122 Tahun 2015, menyatakan sistem distribusi haruslah mampu melayani kebutuhan konsumen dengan memenuhi persyaratan kualitas, kuantitas dan kontinuitas $(3 K)^{(6)}$. Lebih jauh, Direktorat Jendral Cipta Karya menambahkan unsur keterjangkauan pada syarat SPAM sebagai syarat penunjang tercapainya $100 \%$ pelayanan air minum ${ }^{(7)}$. Presentase kehilangan pada air sub sistem distribusi SPAM Beber mencapai 44,38\%, jika dibandingkan dengan kehilangan rata-rata air pada seluruh sistem di PDAM Tirta Jati, maka sistem Beber menyumbang sebesar $25,38 \%{ }^{(8)}$. Kondisi eksisting tersebut menghambat pencapaian 3K. Terlebih Peraturan Bupati Cirebon Nomor 8 Tahun 2016 tentang Rencana Induk Sistem Penyediaan Air Minum Kabupaten Cirebon Tahun 2015 - 2030, angka kehilangan air akan diturunkan secara bertahap menjadi $20 \%$ sampai tahun $2030^{(9)}$.

Namun demikian, hingga saat ini faktorfaktor yang menyebabkan kehilangan air pada sistem distribusi SPAM Beber belum teridentifikasi secara rinci sehingga penanganan yang dilakukan oleh perusahaan belum optimal. Berdasarkan pada permasalahan di atas, maka diperlukan simulasi jaringan distribusi eksisting guna mengidentifikasi permasalahan dan titik kebocoran pada jaringan distribusi eksisting. Hasil simulasi tersebut akan dibandingkan dengan kriteria desain yang tercantum dalam Permen PUPR No. 27 Tahun 2016 sebagai dasar untuk perbaikan jaringan distribusi eksisting ${ }^{(10)}$.

\subsection{Tujuan Penelitian}

Tujuan dari studi ini adalah mengetahui permasalahan pada sistem distribusi eksisting air minum PDAM Tirta Jati Sistem Beber, yaitu:

1. Mengidentifikasi permasalahan ketersediaan air minum pada SPAM Beber;

2. Mengidentifikasi kondisi eksisting SPAM Beber;

3. Melakukan simulasi hidrolis menggunakan software EPANET pada jaringan distribusi eksisting Beber;

4. Membuat usulan optimasi SPAM Beber.

\section{METODE PENELITIAN}

\subsection{Lokasi Penelitian}

Sistem Beber melayani Kecamatan Beber, Kecamatan Talun dan Kecamatan Greged. Sistem Beber menggunakan air yang bersumber dari Mata Air Linggarjati. Kapasitas terpasang untuk Sistem Beber sebesar 75 liter/detik ${ }^{(3)}$.

Sumber air yang berasal dari mata air Linggarjati merupakan hasil perjanjian jual beli air curah yang bekerja sama dengan PDAM Kuningan. Unit transmisi SPAM Beber terbagi menjadi 2 (dua) sistem, yaitu sistem lama menggunakan pipa diameter 10 inci dari Reservoir Linggarjati menuju Reservoir Lama yang terletak di daerah wanayasa dengan kapasitas $200 \mathrm{~m}^{3}$, dan sistem baru menggunakan pipa diameter 10 inci dari Reservoir Linggarjati menuju Reservoir Baru yang terletak di daerah Wanayasa dengan kapasitas $500 \mathrm{~m}^{3}$. Dalam Pelayanannya, SPAM Beber melayani Kelurahan Wanayasa, Sindangkasih, Durajaya, Beber, Patapan, Kondangsari, Sampiran, Ciperna, Kecomberan, Wanasaba Kidul, Bumi Arumsari, dan Kepongpongan. Data yang diperlukan berupa peta jaringan, Daftar Rekening yang Ditagihkan (DRD), debit air, sambungan langganan, dan data teknis pipa yang didapat dari PDAM Tirta Jati. Peta lokasi studi dapat dilihat pada Gambar 1. 


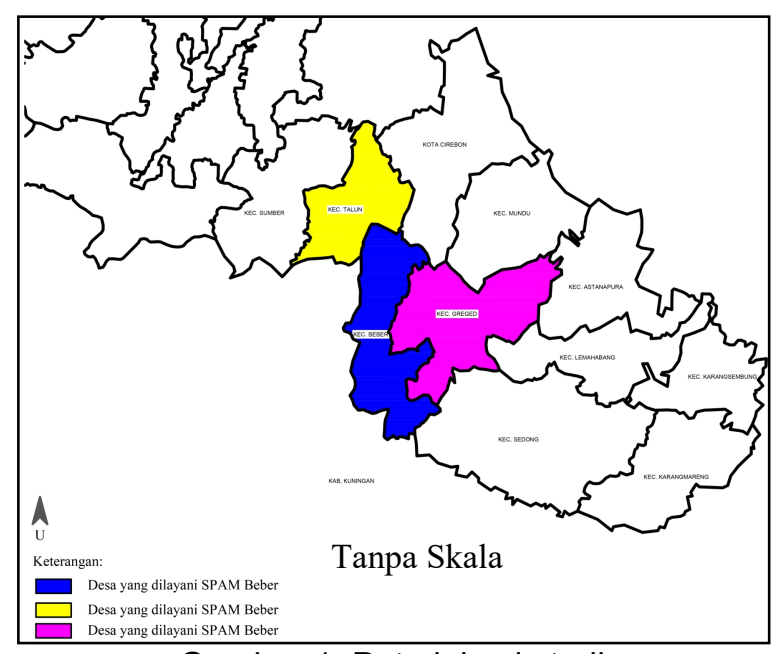

Gambar 1. Peta lokasi studi

\subsection{Evaluasi}

\subsubsection{Evaluasi Kuantitas Air SPAM Beber}

Evaluasi kuantitas air dilakukan guna mengetahui apakah air yang diproduksi oleh PDAM dapat memenuhi kebutuhan air minum pelanggan dengan mengacu pada Direktorat Jendral Cipta Karya 1996 untuk sektor domestik ${ }^{(11)}$, dan Direktorat Jendral Cipta Karya Tahun 1998 untuk sektor non-domestik(12). Evaluasi kuantitas air terdiri dari: (i) evaluasi kapasitas air sebagai input pada sistem distribusi yaitu kapasitas air yang diproduksi untuk memenuhi kebutuhan air sektor domestik dan non-domestik dan (ii) evaluasi output yang merupakan konsumsi air yang dimanfaatkan oleh konsumen. Data yang digunakan meliputi data sambungan langganan, debit produksi, debit pemakaian air eksisting pada bulan April Juli 2019.

\section{a. Evaluasi Kapasitas Air SPAM Beber}

Formula matematis yang digunakan adalah sebagai berikut ${ }^{(13)}$ :

\section{Perhitungan Presentase Pelayanan}

$\%$ domestik $=\frac{\sum \mathrm{D}}{\sum \text { SL }} \times 100 \%$

$\%$ non-domestik $=\frac{\sum \mathrm{ND}}{\sum \mathrm{SL}} \times 100$

Keterangan:

$\sum \mathrm{D}=$ Jumlah sambungan langganan domestik

$\sum \mathrm{ND}=$ Jumlah sambungan langganan non-domestik

$\sum \mathrm{SL}=$ Jumlah total sambungan langganan domestik dan non-domestik

\section{Perhitungan ketersediaan air yang} diproduksi sektor domestik

$\mathrm{a}=\frac{\mathrm{Q}_{\mathrm{am}} x \mathrm{q} \text { domestik }}{\sum \mathrm{P}}$

Keterangan:

a $\quad=$ Ketersediaan air minum untuk setiap

jiwa (L/jiwa/hari)

Qam = Debit produksi (liter/detik)

$\sum \mathrm{P} \quad$ = Jumlah jiwa yang dilayani

$\%$ domestik = Presentase jumlah sambungan

langganan yang terlayani

3. Perhitungan ketersediaan air yang diproduksi sektor non-domestik

$\mathrm{a}=Q_{a m} \times \%$ non-domestik

Keterangan:

a $\quad=$ Ketersediaan air minum untuk setiap

$=$ Debit produksi (liter/detik)

$\%$ non-domestik = Presentase jumlah sambungan

langganan yang terlayani

\section{b. Evaluasi Konsumsi SPAM Beber}

Konsumsi air untuk sektor domestik didapatkan dari penjumlahan pemakaian air pada DRD. Konsumsi pada sektor non-domestik didapatkan melalui penjumlahan air yang digunakan pada setiap unit fasilitas. Formula matematis yang digunakan pada sektor air domestik adalah sebagai berikut ${ }^{(13)}$ :

$\mathrm{a}=\frac{\mathrm{Q}_{\mathrm{SL}}}{\sum \mathrm{p}}$

Keterangan:

$$
\begin{array}{ll}
\mathrm{a} & =\begin{array}{l}
\text { Ketersediaan air minum untuk setiap orang } \\
(\mathrm{L} / \text { orang/hari })
\end{array} \\
\mathrm{QSL}_{\mathrm{SL}} & =\text { Pemakaian air pelanggan } \\
\sum \mathrm{P} & =\text { Jumlah jiwa yang dilayani }
\end{array}
$$

\subsubsection{Evaluasi Kontinuitas Air SPAM Beber}

Evaluasi kontinuitas air merupakan evaluasi terkait ketersediaan air selama 24 jam dalam sehari. Dalam pengalirannya SPAM harus mampu melayani wilayah pelayanan selama 24 jam menurut Permen PUPR No. 27 Tahun 2016. Pengaliran selama 24 jam ini untuk memastikan setiap pelanggan mendapatkan pelayanan air yang kontinu.

\subsubsection{Evaluasi Pola Pemakaian Air SPAM Beber}

Pola pemakaian air didapatkan dari dokumen pencatatan meter air. Data yang digunakan merupakan debit air yang tercatat setiap jamnya pada meter induk air dalam satu hari di bulan Juli 2019. Data yang digunakan merupakan data paling terbaru, dikarenakan 
PDAM tidak selalu melakukan pembacaan meter induk selama 24 jam dalam sehari. Hasil pembacaan debit air tersebut dianalisis menggunakan rumus sebagai berikut ${ }^{(14)}$ :

fh $=\frac{Q}{x}$

Keterangan:

$\mathrm{fh}=$ Faktor pemakaian air setiap jam nya

$\mathrm{Q}=$ Debit air setiap jam nya (liter/detik)

$\bar{X}=$ Debit rata-rata dalam sehari (liter/detik)

\subsubsection{Evaluasi Kehilangan Air SPAM Beber}

Evaluasi dilakukan menggunakan neraca air pada metode yang ditetapkan oleh International Water Association (IWA)(15). Neraca tersebut akan mengidentifikasi faktor penyebab kehilangan air berdasarkan klasifikasi kehilangan air. Kehilangan air atau Non-revenue Water (NRW) terdiri dari kehilangan fisik dan kehilangan komersial (non-fisik), kehilangan air komersial merupakan kehilangan air yang diakibatkan oleh air yang tidak dapat dibayarkan oleh konsumen atau adanya sambungan ilegal serta kesalahan pembacaan meter air, sedangkan kehilangan air fisik disebabkan oleh air yang hilang secara fisik (perpipaan) ${ }^{(16)}$. Karena adanya situasi pandemi saat ini, data yang digunakan adalah data terbaru pemakaian air yang diperoleh dari DRD, daftar sisa rekening, serta daftar rekening perbaikan pada bulan Juli 2019 .

\subsubsection{Simulasi Hidrolis SPAM Beber}

Simulasi hidrolis dilakukan menggunakan software EPANET 2.0. Data yang dibutuhkan dalam tahap ini adalah diameter, panjang pipa dan jenis pipa sebagai nilai koefisien pipa untuk data penunjang link atau pipa pada program, serta data pemakaian air dari DRD bulan Juli 2019 dan elevasi muka tanah sebagai data penunjang node atau junction. Selain data pipa dan node, terdapat juga data pola pemakaian air yang digunakan sebagai demand pattern. Hasil simulasi kemudian ditinjau dari sisa tekan, kecepatan pada pipa dan kehilangan tekanan. Rumus yang digunakan pada simulasi adalah formula Hazen-Wiliam sebagai berikut ${ }^{(13)}$ :

$$
Q=0,2785 \times C \times D^{2,63} x\left(\frac{h f}{L}\right)^{0,54}
$$

Keterangan:

$$
\begin{array}{ll}
\mathrm{Q} & =\text { debit air yang mengalir }\left(\mathrm{m}^{3} /\right. \text { detik) } \\
\mathrm{C} & =\text { Koefisien Hazen William } \\
\mathrm{Hf} & =\text { Kehilangan tekanan }(\mathrm{mka}) \\
\mathrm{L} & =\text { Panjang pipa }(\mathrm{m})
\end{array}
$$

Hasil dari simulasi akan dibandingkan dengan Permen PUPR No. 27 Tahun 2016 berupa: (a) sisa tekan 10 - 12,4 MPa, sisa tekan dipertimbangkan agar daerah pelayanan terjauh mendapatkan suplai air yang cukup; (b) kecepatan pada pipa $(0,3-3,0) \mathrm{m} /$ detik, kecepatan pada pipa dipertimbangkan guna memelihara pipa agar tidak cepat rusak. Kecepatan minimum diharapkan agar tidak terjadi endapan, dan kecepatan maksimum diharapkan agar pipa tidak mudah pecah; (c) kehilangan tekanan kurang dari $10 \mathrm{~m} / \mathrm{km}$, hal ini dipertimbangkan guna memperkecil kehilangan energi selama pengaliran.

\subsubsection{Pengoptimalan Jaringan Distribusi SPAM Beber}

Optimalisasi jaringan distribusi dilakukan pada daerah yang tidak sesuai dengan kriteria desain, di mana pengoptimalan dapat dilakukan dengan pergantian diameter ${ }^{(17)}$ dan pemasangan washout guna menguras atau mengeluarkan endapan yang terbentuk dalam pipa karena pipa yang memiliki nilai kecepatan aliran tidak sesuai dengan kriteria desain(18). Daerah yang memiliki sisa tekan air yang besar dapat ditanggulangi dengan pemasangan Bak Pelepas Tekan (BPT)(19). Selain BPT, dapat juga dilakukan pemasangan Pressure Reducing Valve (PRV) untuk daerah yang memiliki sisa tekan melebihi kriteria(20) dan pemasangan pompa booster untuk daerah yang memiliki sisa tekan kurang dari kriteria desain. Tekanan dalam pipa dapat dipengaruhi juga oleh kebocoran, ketika terjadi kebocoran besarnya tekanan dalam pipa akan berpengaruh akibat adanya jumlah air yang terbuang melalui titik kebocoran. Pengaturan tekanan dapat dilakukan dengan berbagai cara untuk menaikkan tekanan dapat digunakan pompa pada saat jam pemakaian puncak untuk membantu meningkatkan tekanan jika tekanan yang diterima konsumen kurang pada jam puncak. Tekanan yang berlebih dapat menyebabkan kerusakan pada pipa, dimana pipa-pipa akan mudah bocor sehingga dapat meningkatkan presentase kebocoran dalam jaringan distribusi, guna mengatur tekanan berlebih dapat digunakan PRV dan $\mathrm{BPT}^{(21)}$.

\section{HASIL DAN PEMBAHASAN}

\subsection{Evaluasi Kuantitas Air SPAM Beber}

\subsubsection{Kapasitas Air}

\section{a. Sektor Domestik}

Total jumlah sambungan langganan untuk Cabang Beber hingga bulan April - Juli 2019 secara berurutan adalah 4.899, 4.968, 5.002, dan 5.100, sebagaimana diperlihatkan pada Tabel 1. Sementara itu, debit produksi air minum pada bulan April - Juli 2019 tercatat berada pada rentang $(60,36-72,58)$ liter/detik $^{(8)}$. 
Jumlah jiwa yang dilayani oleh Sistem Beber merupakan hasil perkalian antara jumlah SL setiap desa dengan jumlah jiwa/SL. Berdasarkan hasil perhitungan, ketersediaan air minum yang dipenuhi oleh PDAM Tirta Jati Cabang Beber pada bulan April - Juli sebesar $(263,00$ - 323,11) liter/hari. Berdasarkan Kriteria Perencanaan Direktorat Jenderal Cipta Karya PU Tahun 1996, standar kebutuhan pokok air minum untuk kota kecil adalah sebesar 110 liter/jiwa/hari(11). Jika dibandingkan dengan standar kebutuhan air minum selama periode bulan April - Juli, PDAM Tirta Jati Cabang Beber sudah memenuhi standar kebutuhan air minum untuk konsumen.

\section{b. Sektor Non-domestik}

Jumlah sambungan langganan pada sektor non-domestik pada bulan April - Juli sebanyak (142 - 145) SL, sementara persentase SL terhadap total keseluruhan SL adalah sebesar $(2,84-2,90) \%$, sebagaimana ditampilkan pada Tabel 2. Total standar kebutuhan air untuk sektor non-domestik pada bulan April - Juli adalah sebesar $(122.098$ - 123.980) liter/hari(12). Tabel 2 juga memperlihatkan bahwa ketersediaan air untuk non-domestik pada periode April - Juli adalah sebanyak $(148.108,96$ - 179.348,08) liter/hari. Hal ini menunjukan kebutuhan air minum untuk nondomestik lebih kecil dibandingkan ketersediaan air yang diproduksi oleh PDAM Tirta Jati Cabang Beber. Dengan kata lain, jumlah air yang diproduksi selama periode bulan April - Juli, SPAM Beber mampu memenuhi kebutuhan air sektor non-domestik jika dibandingkan dengan standar kebutuhannya.

\subsubsection{Konsumsi SPAM Beber}

\section{a. Sektor Domestik}

Pemakaian air pelanggan Sistem Beber pada bulan April - Juli 2019 sebesar 65.980, 70.822 , 76.383, dan $79.180 \mathrm{~m}^{3}$, secara berurutan dengan total jumlah penduduk sebesar 18.547 - 19.266 jiwa terlayani, sebagaimana ditunjukkan pada Tabel 3 . Sementara itu, pemakaian air minum pelanggan eksisting sistem Cabang Beber pada periode yang sama adalah sebesar (114,76 - 132,58) liter/jiwa/hari. Jika dibandingkan dengan standar kebutuhan air minum menurut Ditjen Cipta Karya Tahun 1996 (110 liter/jiwa/hari), pemakaian air minum pelanggan eksisting ini relatif tinggi. Standar kebutuhan air minum tersebut merupakan standar kebutuhan untuk kota kecil, di mana standar kebutuhan air yang diperuntukkan mandi, minum, masak, cuci pakaian, peturasan, dan ibadah. Untuk area yang dilayani SPAM Beber, konsumsi air sektor domestik juga digunakan untuk mencuci kendaraan pribadi, menyiram tanaman, kebersihan rumah, serta terdapat rumah-rumah yang memiliki kolam ikan dan kolam renang pribadi di dalam rumahnya yang membutuhkan air dalam operasional dan pemeliharaannya.

Tabel 1. Evaluasi kapasitas air sektor domestik

\begin{tabular}{|c|c|c|c|c|c|c|c|c|}
\hline \multirow{2}{*}{ Bulan } & \multicolumn{2}{|c|}{$\begin{array}{l}\text { Sambungan } \\
\text { Langganan }\end{array}$} & \multirow{2}{*}{$\% S L$} & \multicolumn{2}{|c|}{ Debit Produksi } & \multirow{2}{*}{$\begin{array}{l}\text { Jumlah } \\
\text { Jiwa }\end{array}$} & \multicolumn{2}{|c|}{ Ketersediaan } \\
\hline & Total & D & & $\mathrm{m}^{3} / \mathrm{bulan}$ & L/detik & & L/detik & L/jiwa/hari \\
\hline April & 4.899 & 4.757 & 97,10 & 175.000 & 65,34 & 18.547 & 25,46 & 295,55 \\
\hline Mei & 4.968 & 4.826 & 97,14 & 170.304 & 63,58 & 18.725 & 27,32 & 285,00 \\
\hline Juni & 5.002 & 4.859 & 97,14 & 194.396 & 72,58 & 18.853 & 29,47 & 323,11 \\
\hline Juli & 5.100 & 4.955 & 97,16 & 161.672 & 60,36 & 19.266 & 30,55 & 263,00 \\
\hline
\end{tabular}

Tabel 2. Evaluasi kapasitas sektor non-domestik

\begin{tabular}{|c|c|c|c|c|c|c|c|c|}
\hline \multirow{2}{*}{ Bulan } & \multicolumn{2}{|c|}{$\begin{array}{l}\text { Sambungan } \\
\text { Langganan }\end{array}$} & \multirow{2}{*}{$\% S L$} & \multicolumn{2}{|c|}{ Debit Produksi } & \multirow{2}{*}{$\begin{array}{c}\text { Standar } \\
\text { Kebutuhan } \\
\text { (L/hari) }\end{array}$} & \multicolumn{2}{|c|}{ Ketersediaan } \\
\hline & Total & SL ND & & $\mathrm{m}^{3} / \mathrm{bulan}$ & L/detik & & $\mathrm{m}^{3} / \mathrm{bulan}$ & L/hari \\
\hline April & 4.899 & 142 & 2,90 & 175.000 & 65,34 & 122.098 & $5.075,00$ & $163.715,90$ \\
\hline Mei & 4.968 & 142 & 2,86 & 170.304 & 63,58 & 122.098 & $4.870,69$ & $157.108,72$ \\
\hline Juni & 5.002 & 143 & 2,86 & 194.396 & 72,58 & 123.598 & $5.559,73$ & $179.348,08$ \\
\hline Juli & 5.100 & 145 & 2,84 & 161.672 & 60,36 & 123.980 & $4.591,48$ & $148.108,96$ \\
\hline
\end{tabular}


Tabel 3. Evaluasi konsumsi air sektor domestik

\begin{tabular}{lcccc}
\hline \multirow{2}{*}{ Bulan } & \multirow{2}{*}{$\begin{array}{c}\text { Jumlah } \\
\text { Jiwa }\end{array}$} & \multicolumn{2}{c}{ Pemakaian } & Konsumsi \\
\cline { 3 - 5 } & & $\mathbf{m}^{3}$ /bulan & L/detik & L/jiwa/hari \\
\hline April & 18.547 & 65.980 & 25,46 & 114,76 \\
\hline Mei & 18.725 & 70.822 & 27,32 & 122,01 \\
\hline Juni & 18.853 & 76.383 & 29,47 & 130,69 \\
\hline Juli & 19.266 & 79.180 & 30,55 & 132,58 \\
\hline
\end{tabular}

Tabel 4. Evaluasi kapasitas sektor non-domestik

\begin{tabular}{lccc}
\hline \multirow{2}{*}{ Bulan } & \multirow{2}{*}{$\begin{array}{c}\text { Standar } \\
\text { Kebutuhan (L/hari) }\end{array}$} & \multicolumn{2}{c}{ Pemakaian } \\
\cline { 3 - 4 } & & $\mathbf{m}^{3}$ /bulan & L/hari \\
\hline April & 122.098 & 9.534 & $307.548,39$ \\
\hline Mei & 122.098 & 6.089 & $196.419,35$ \\
\hline Juni & 123.598 & 6.506 & $209.870,97$ \\
\hline Juli & 123.980 & 10.558 & $340.580,65$ \\
\hline
\end{tabular}

\section{b. Sektor Non-domestik}

Dari data air yang terjual, didapatkan data pemakaian sektor non-domestik pada bulan April - Juli adalah sebesar 307.548, 196.419, 209.870, dan 340.580 liter/hari secara berurutan. Tabel 4 memperlihatkan standar kebutuhan air yang dibutuhkan pada periode April - Juli, yakni 122.098, 122.098, 123.598, dan 123.980 liter/hari. Pada periode yang ditinjau, pemakaian air non-domestik lebih besar dibandingkan standar kebutuhan air yang dibutuhkan. Oleh karena itu, jika dibandingkan dengan pemakaian air eksisting, PDAM Tirta Jati Cabang Beber tidak mampu memenuhi standar kebutuhan pokok air minum sektor non-domestik tersebut. Pemakaian air yang lebih besar dibandingkan standar kebutuhan pokok disebabkan oleh ketersediaan air di fasilitas yang ada termanfaatkan tidak sesuai dengan standar kebutuhannya.

\subsection{Evaluasi Kontinuitas dan Pola Pemakaian Air SPAM Beber}

Reservoir Linggarjati sebagai reservoir yang menampung air baku untuk Cabang Beber melayani masyarakat Kecamatan Beber dan Kecamatan Talun secara kontinyu selama 24 jam dalam sehari. PDAM Tirta Jati Cabang Beber tidak melakukan pengukuran tekanan air di sambungan langganan, sehingga tidak diketahui secara pasti berapa jam pelayanan distribusi ke konsumen mendapatkan pengaliran air. Dari hasil keterangan dari Bagian Pelayanan Teknik Cabang Beber pada bulan Juli 2019, pelayanan pengaliran air hingga ke konsumen yaitu selama 24 jam. Dari data di atas diketahui bahwa Sistem Cabang Beber sudah memenuhi syarat kontinuitas selama 24 jam sesuai dengan Permen PUPR No. 27 Tahun 2016.

Fluktuasi pengaliran pada meter induk merupakan fluktuasi penggunaan air setiap jamnya yang tercatat dalam meter induk. Fluktuasi pengaliran ini bertujuan untuk mengetahui variasi penggunaan air setiap jamnya, serta mengetahui penggunaan air puncak maupun minimum yang kemudian digunakan sebagai demand pattern dalam software EPANET 2.0. Fluktuasi pemakaian air didapatkan dari hasil pembacaan meter induk air selama 24 jam. Pada Sistem Beber terdapat 2 Jaringan Distribusi Utama, yaitu pendistribusian air pada Jaringan Distribusi Utama (JDU) lama yang memiliki jam puncak pada pukul $04.00-06.00$ sebesar 1,17 dan pendistribusian pada JDU baru yang memiliki jam puncak pada pukul 05.00 - 06.00 dengan faktor puncak sebesar 1,15 . Fluktuasi pemakaian air dapat dilihat pada Gambar 2.

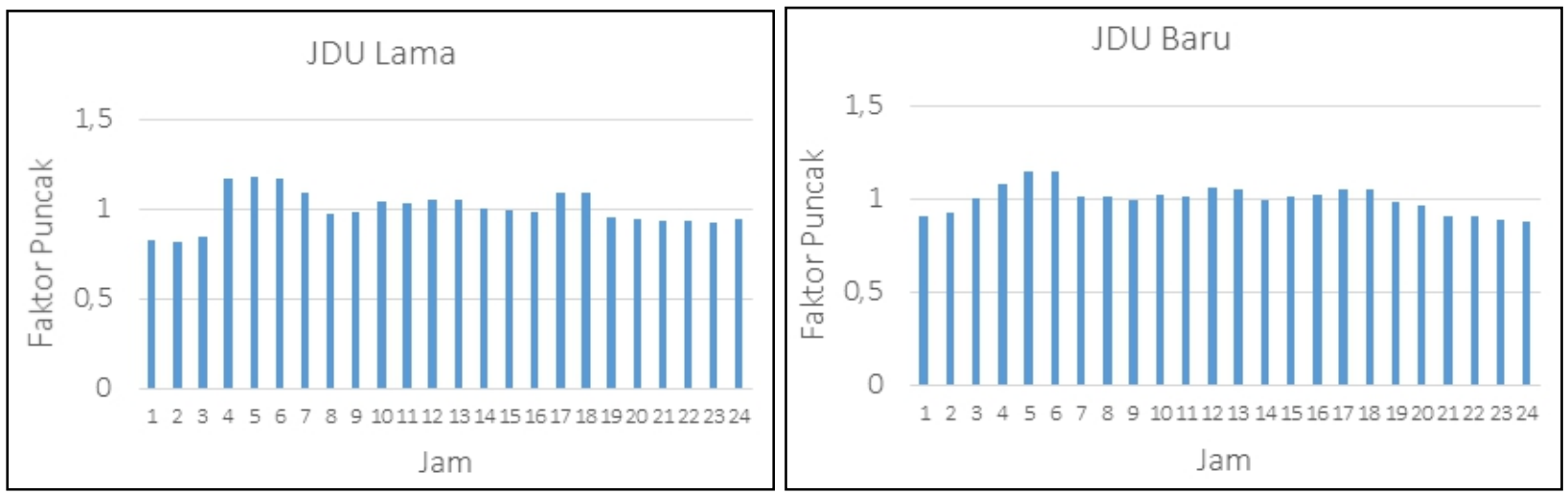

Gambar 2. Fluktuasi pemakaian air 
Tabel 5. Presentase kehilangan air

\begin{tabular}{lcccc}
\hline Bulan & $\begin{array}{c}\text { Debit Produksi } \\
\text { (m3/bulan) }\end{array}$ & $\begin{array}{c}\text { Pemakaian Air } \\
\text { (m3/bulan) }\end{array}$ & $\begin{array}{c}\text { Selisih Pemakaian Air } \\
\text { (m3/bulan) }\end{array}$ & Kehilangan Air (\%) \\
\hline April & 175.000 & 75.514 & 99.486 & 56,84 \\
\hline Mei & 170.304 & 70.886 & 99.418 & 58,38 \\
\hline Juni & 194.396 & 82.889 & 111.507 & 57,36 \\
\hline Juli & 161.672 & 89.738 & 71.934 & 44,49 \\
\hline
\end{tabular}

Fluktuasi pemakaian air ini berbeda dikarenakan pola konsumsi masyarakat yang berbeda setiap jamnya. Kecamatan Beber dan Kecamatan Talun memiliki jumlah 28.447 dan 46.807 jiwa penduduk berusia produktif serta 11.455 dan 15.297 jiwa usia pelajar, di mana masyarakat golongan tersebut memulai aktivitasnya di rentang waktu yang sama yaitu pagi hari. Hal ini dapat menjelaskan mengapa jam puncak pada kedua kecamatan terdapat pada rentang waktu pukul 05.00 - 06.00 . Pemakaian air dipengaruhi juga oleh tingkatan pendapatan atau kesejahteraan. Keluarga pra sejahtera memiliki pendapatan yang tergolong rendah dibandingkan keluarga sejahtera. Semakin tinggi kesejahteraan suatu keluarga maka pemakaian airnya juga akan semakin tinggi( ${ }^{(22)}$. Kecamatan Beber masih memiliki total 608 keluarga yang tergolong pra sejahtera(23), dibandingkan Kecamatan Talun yang mayoritasnya merupakan keluarga sejahtera.

Mayoritas tingkat kesejahteraan pada Kecamatan Talun yaitu wilayah yang dilayani oleh JDU baru adalah keluarga sejahtera II sehingga pemakaian air tidak hanya untuk mandi dan masak, masyarakat sekitar juga memiliki kebiasaan menyiram jalanan yang kering karena daerah sekitar yang kurang akan penghijauan serta mencuci kendaraan pribadinya.

\subsection{Evaluasi Kehilangan Air SPAM Beber}

Kehilangan air didefinisikan sebagai perbedaan antara jumlah air yang diproduksi dengan air yang dijual atau didistribusikan kepada pelanggan melalui meter air(22).

Tabel 5 memperlihatkan permasalahan utama yang dihadapi PDAM Sistem Beber, yakni tingkat kebocoran pipa distribusi yang tinggi. Pada periode April-Juli 2019, total air yang diproduksi sebanyak $175.000 \mathrm{~m}^{3}$ (April), $170.304 \mathrm{~m}^{3}$ (Mei), $194.396 \mathrm{~m}^{3}$ (Juni), dan $161.672 \mathrm{~m}^{3}$ (Juli). Namun, jumlah air yang terjual hanya sebesar $75.514 \mathrm{~m}^{3}$ (April), 70.886 $\mathrm{m}^{3}$ (Mei), $82.889 \mathrm{~m}^{3}$ (Juni), dan $89.738 \mathrm{~m}^{3}$ (Juli), di mana terdapat selisih $99.486 \mathrm{~m}^{3}$ (April), $99.418 \mathrm{~m}^{3}$ (Mei), $111.507 \mathrm{~m}^{3}$ (Juni), dan 71.934 $\mathrm{m}^{3}$ (Juli) air yang tidak terjual ke konsumen atau sebesar 44,49-58,38\%. Hasil evaluasi kehilangan air ini menunjukkan bahwa persentase kehilangan air bulan April - Juli pada SPAM Beber melebihi standar nilai NRW yang ditoleransi, yaitu sebesar $18-20 \%$.

Air yang tidak terjual ke konsumen tersebut termasuk dalam NRW atau kehilangan air. Dari data didapatkan jika terdapat konsumsi resmi tidak berekening tercatat sebesar $18.077 \mathrm{~m}^{3}$ (data NRW hanya tersedia pada bulan Juli 2019). Konsumsi resmi tidak berekening ini berupa pemakaian air yang belum dibayar oleh pelanggan $^{(24)}$. Selain itu terdapat juga kehilangan air komersial yaitu kesalahan pembacaan meter air dan administratif pada sistem di PDAM sebesar $176 \mathrm{~m}^{3}$ (data hanya tersedia pada bulan Juli 2019)(25). Selain itu, didapatkan juga kebocoran pada pipa distribusi dan servis sebesar $71.758 \mathrm{~m}^{3}$ (data hanya tersedia pada bulan Juli 2019). Kebocoran pada pipa transmisi tidak diketahui, karena sumber air yang digunakan berasal dari PDAM Tirta Kamuning di mana pipa transmisi merupakan otoritas dari pihak PDAM Tirta Kamuning Kabupaten Kuningan.

\subsection{Simulasi Hidrolis Jaringan Distribusi Eksisting SPAM Beber}

Simulasi hidrolis dilakukan dengan menggunakan software EPANET 2.0, dimana jenis pipa eksisting yang digunakan adalah HDPE dengan nilai C sebesar 120. Hasil simulasi yang ditinjau berada pada pukul 05.00. Hasil simulasi yang ditinjau berupa sisa tekan, kecepatan aliran dalam pipa, dan headloss. Hasil simulasi kemudian dibandingkan dengan Permen PUPR No. 27 Tahun 2016.

Hasil simulasi sebagaimana diperlihatkan pada Gambar 3 menunjukkan bahwa sisa tekan pada jaringan eksisting berada pada rentang nilai 10,08-131,24 mka. Sebanyak 147 junction atau $100 \%$ junction memenuhi kriteria desain yaitu daerah yang memiliki tekanan kurang dari 12,4 MPa, jika dibandingkan dengan Permen PUPR No. 27 Tahun 2016, kriteria sisa tekan sudah memenuhi kriteria meliputi sekitar daerah; Wanayasa, Sindangkasih, Blok Depok. Selain itu, terdapat daerah yang memiliki sisa tekan lebih besar dari 100 mka, yaitu daerah sekitar Graha Beber Raya. Karena, pipa HDPE yang digunakan dalam eksisting merupakan pipa jenis HDPE SDR-17. Jika dibandingkan dengan 
tekanan kerja pipa di lapangan, pipa HDPE yang di produksi oleh pabrik memiliki maksimum tekanan kerja hingga 100 mka untuk pipa SDR17. Hal ini dikarenakan industri air membutuhkan design life minimal 50 tahun. Sisa tekan yang tidak memenuhi kriteria desain ditandai dengan kotak warna merah pada Gambar 3. Tekanan yang berlebih pada pipa HDPE ini akan menyebabkan berbagai macam masalah, salah satunya ialah penyebab kebocoran pada pipa. Maka dari hasil simulasi perlu adanya optimasi jaringan untuk menurunkan sisa tekan. Jika ditinjau dari hasil kecepatan, nilai kecepatan berada pada rentang nilai $0,01-0,86 \mathrm{~m} /$ detik, di mana pipa yang tidak memenuhi kriteria tersebut ditandai dengan kotak warna biru pada Gambar 3, sepanjang 15.635,04 meter pipa tidak memenuhi kriteria desain. Kecepatan aliran dalam pipa kurang dari 0,3 m/detik yang meliputi daerah sekitar Sindangkasih, Kondangsari, Dusun Pahing, Kepongpongan, Kliwon, Patapan, Beber, Ciperna, dan Sampiran Indah. Sedangkan hasil simulasi headloss berada pada rentang nilai $0,01-4,67 \mathrm{~m} / \mathrm{km}$, rentang nilai ini sudah sesuai dengan kriteria desain, yaitu kurang dari 10 $\mathrm{m} / \mathrm{km}$ meliputi daerah Wanayasa, Sindangkasih, Mandi Angin, dan Arumsari.

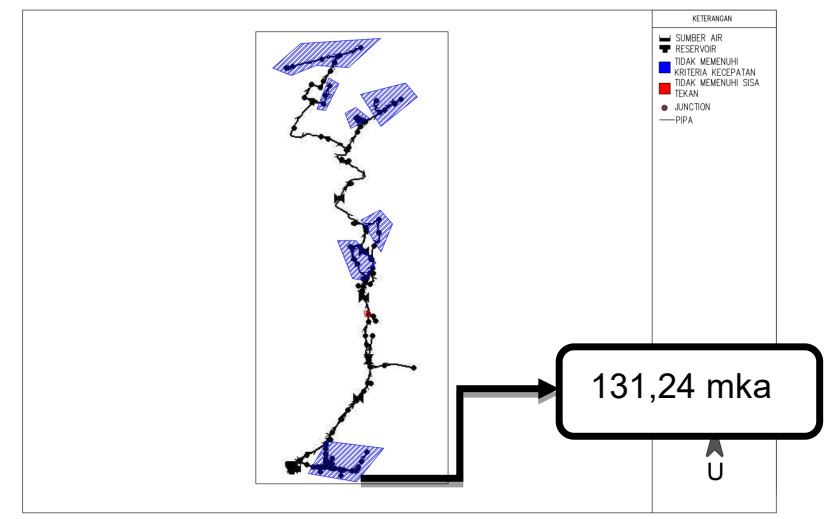

Gambar 3. Hasil simulasi

\subsection{Pengoptimalan SPAM Beber}

Berdasarkan hasil simulasi diketahui bahwa selama pendistribusiannya, jaringan distribusi eksisting tidak memenuhi kriteria baik dalam sisa tekan dan kecepatan aliran. Wilayah pelayanan yang jaringan pipanya memiliki sisa tekan lebih besar dari 100 mka dapat ditanggulangi dengan pemasangan PRV. PRV diletakkan pada sisa tekan yang melebihi 60 mka karena diharapkan sisa tekan maksimum pada wilayah pelayanan berada dalam rentang 60 - 80 mka. Tekanan kerja PRV untuk mengurangi tekanan hingga sebesar $80 \%$. Pada simulasi peletakkan PRV dalam EPANET, dipasang valve PRV dengan setting sisa tekan yang diharapkan. Dalam SPAM Beber, 3 PRV diletakkan pada 3 lokasi berbeda. PRV 1 diletakkan pada daerah Beber dengan outlet 20 mka, PRV diletakkan di daerah Graha Beber Raya dengan outlet tekanan sebesar $15 \mathrm{mka}$, dan PRV 3 pada daerah Patapan dengan outlet tekanan sebesar $15 \mathrm{mka}$. Berikut ini merupakan gambaran peletakkan PRV, seperti yang dapat dilihat pada Gambar 4. Pada wilayah yang memiliki kecepatan tidak sesuai dengan kriteria desain dapat ditanggulangi dengan pergantian diameter pipa pada jaringan yang tidak sesuai kriteria desain, pipa dengan diameter lebih kecil untuk nilai kecepatan aliran di bawah 0,3 $\mathrm{m} /$ detik. Hasil pergantian diameter pipa didapatkan, yang semula pipa sekunder pada SPAM Beber berada dalam rentang $6-2$ inci, setelah pergantian diameter pipa didapatkan bahwa rentang diameter pipa sekunder pada SPAM Beber menjadi $4-1 / 2$ inci. Hasil peletakkan 3 PRV diatas didapatkan hasil sisa tekan maksimum pada wilayah pelayanan menjadi 66,75 mka.

Sementara itu, dalam upaya mengidentifikasi titik kebocoran dapat ditanggulangi dengan pemasangan District Meter Area (DMA), dimana pembentukan zonazona pelayanan dilakukan dengan mempertimbangkan batas administrasi ataupun perbedaan elevasi tanah pada wilayah pelayanan. Zona yang terbentuk harus terisolasi(26) dan akan dipasang meter air untuk memudahkan identifikasi kebocoran dengan melihat selisih pemakaian air yang tercatat dalam meter air dengan jumlah air yang terjualnya ${ }^{(27)}$. Langkah ini menjadi sangat strategis dilakukan mengingat sistem penyediaan air minum harus dilakukan sesuai prinsip kehati-hatian, terlebih di Kota Besar di Indonesia sumber air telah mengalami penurunan kualitas ${ }^{(28-29)}$, sehingga sangat penting untuk mencegah kebocoran air minum pada sistem distribusi. 


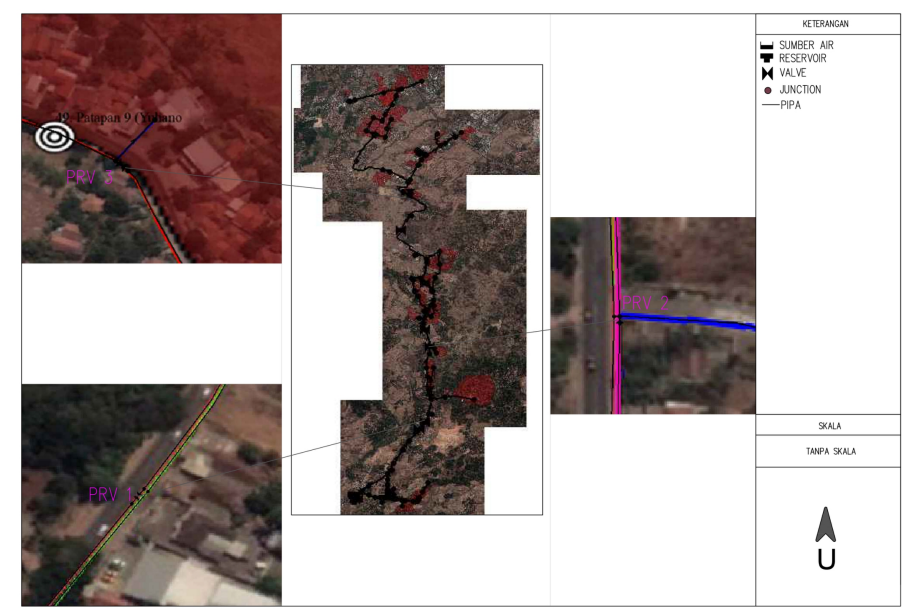

Gambar 4. Peletakkan PRV

\section{KESIMPULAN}

Pada Sistem Beber, dari total 60,36 L/detik air yang diproduksi pada bulan Juli 2019, kapasitas tersebut sudah mampu memenuhi kebutuhan air sebesar 263,00 liter/jiwa/hari dalam wilayah pelayanan Sistem Beber. Pada kondisi eksisting jaringan distribusi air minum, air yang diproduksi tidak sepenuhnya terdistribusikan ke pelanggan. Total kehilangan air pada jaringan distribusi eksisting SPAM Beber mencapai angka $44,38 \%$, sebanyak $71.758 \mathrm{~m}^{3}$ air hilang akibat kebocoran pada pipa distribusi eksisting.

Dari hasil evaluasi didapatkan bahwa hasil simulasi hidrolis menunjukkan bahwa pada pendistribusiannya sebanyak 147 junction sudah sesuai kriteria desain, yaitu wilayah yang memiliki sisa tekan kurang dari 12,4 MPa serta pada wilayah Graha Beber Raya, sisa tekannya lebih besar dari $100 \mathrm{mka}$, yaitu nilai tekanan maksimum yang diterima oleh pipa yang diproduksi oleh pabrikan. Selain itu, terdapat wilayah pelayanan yang memiliki kecepatan aliran kurang dari 0,3 $\mathrm{m} /$ detik. Panjang pipa yang tidak sesuai kriteria desain tersebut sepanjang 15.635,04 meter. Perbaikan yang dapat dilakukan untuk menanggulangi sisa tekan adalah pemasangan PRV, sedangkan untuk wilayah pelayanan yang tidak memenuhi kriteria kecepatan aliran dapat ditanggulangi dengan pergantian diameter pipa menjadi $4-1 / 2$ inci. Hasil evaluasi tersebut dapat dijadikan sebagai dasar acuan untuk mengidentifikasi permasalahan dan titik kebocoran yang terjadi pada jaringan distribusi eksisting. Dalam upaya mengidentifikasi titik kebocoran, dapat dilakukan pemasangan DMA untuk mempermudah penanganan titik kebocoran.

\section{PERSANTUNAN}

Penulis Pertama menyampaikan terima kasih kepada Bapak Arie Harianyah yang sudah banyak membantu penulis selama mengolah data. Penulis juga ingin menyampaikan terima kasih kepada seluruh staf PDAM Tirta Jati pusat dan PDAM Tirta Jati Cabang Beber yang telah membantu dalam memberikan data-data yang penulis butuhkan untuk menulis naskah. Terima kasih juga kepada Syanocty Putri selaku partner pengerjaan Tugas Akhir yang telah banyak memberikan dukungan kepada penulis.

\section{DAFTAR PUSTAKA}

1. Kalensun, H., Kawet, L., \& Halim, F. (2016). Perencanaan Sistem Jaringan Distribusi Air Bersih di Kelurahan Pengolombian Kecamatan Tomohon Selatan. Jurnal Sipil Statik, 4(2), 105 - 115.

2. Zolapora, B., Joshipura, N., \& Patel, J. (2015). Case Study on Designing Water Supply Distribution Network Using EPANET for Zone1 of Village Kherali. Indian Journal of Research 4(7), 51 - 54.

3. PDAM Tirta Jati. (2019). Laporan Bulanan Bidang Teknik Bulan Juli 2019 Cabang Beber.Cirebon: PDAM Tirta Jati.

4. PDAM Tirta Jati. (2019b). Daftar Rekening Ditagihkan Juli 2019. Cirebon: PDAM Tirta Jati

5. Maryati, S., \& Arika, D. M. (2008). Penerapan Water Demand Management di Kelurahan Setiamanah, Kota Cimahi. Jurnal Perencanaan Wilayah dan Kota, 1(1), 69 - 87.

6. Peraturan Pemerintah. (2015). Peraturan Pemerintah No. 122 Tahun 2015 tentang Sistem Penyediaan Air Minum. Lembar Negara RI No. 345 Tahun 2015. Jakarta: Sekretariat Negara.

7. Nugraha, I. R., Sururi, M. R., Sulistiowati, L. A. (2017). Evaluasi Sistem Distribusi Air Minum PDAM Tirta Kerta Raharja Cabang Teluknaga 
Kabupaten Tangerang. Jurnal Teknik Lingkungan, 23(1), 87 - 89.

8. PDAM Tirta Jati. (2019c). Laporan Bulanan Produksi Air Bulan Juli 2019 Cabang Beber.Cirebon: PDAM Tirta Jati

9. Bupati Cirebon. (2016). Peraturan Bupati Cirebon Nomor 8 Tahun 2016 tentang Rencana Induk Sistem Penyediaan Air Minum Kabupaten Cirebon Tahun 2015 - 2030. Lembaran Negara RI Tahun 2016. Kabupaten Cirebon: Sekretaris Daerah.

10. Menteri Pekerjaan Umum dan Perumahan Rakyat Republik Indonesia. (2016). Peraturan Menteri Pekerjaan Umum dan Perumahan Rakyat Nomor 27 Tahun 2016 tentang Penyelenggaraan Sistem Penyediaan Air Minum. Lembaran Negara RI Tahun 2016 No. 27. Jakarta: Sekretariat Negara.

11. Direktorat Jenderal Cipta Karya Departemen Pekerjaan Umum. (1996). Kriteria Perencanaan Air Bersih. Jakarta: Departemen Pekerjaan umum.

12. Direktorat Jenderal Cipta Karya Departemen Pekerjaan Umum. (1998). Petunjuk Teknis Sistem Penyediaan Air Minum Perkotaan. Jakarta: Departemen Pekerjaan Umum.

13. Twort, A.C., Law, F. M., Crowley, F. W., \& Ratnayaka, D. D. (1994). Water Supply $\left(4^{\text {th }}\right.$ Edition). London: Edward Arnold (Publisher) Ltd.

14. Syahputra, B. (2020). Penentuan Faktor Jam Puncak dan Harian Maksimum Terhadap Pola Pemakaian Air Domestik Di Kecamatan Kalasan, Sleman, Yogyakarta. Jurnal Lingkungan, 1(1), 1-15.

15. Lambert, A., \& Hirner, W. (2000). Losses from Water Supply Systems: Standards Terminology and Recommended Performance Measures. International Water Association: The Blue Pages.

16. Annisa, A. N. (2016). Studi Literature Perencanaan dan Algoritma Pembentukan DMA (District Meter Area). Disertasi. Institut Teknologi Sepuluh November.

17. Nugroho, S., Meichayanti, I., \& Nurdiana, J. (2018). Analisa Jaringan Perpipaan Distribusi Air Bersih Menggunakan EPANET 2.0 (Studi Kasus di Kelurahan Harapan baru, Kota Samarinda). Teknik, 39(1), $62-66$.

18. Pristiawan, E. (2019). Studi Evaluasi dan Perencanaan Pengembangan Jaringan Distribusi Air Bersih Daerah Layanan Instalasi
Pengolahan Air (IPA) Kampung Bugis Kota Tarakan. Disertasi. Universitas Muhammadiyah Malang.

19. Nugraha, W. D., \& Oktiawan, W. (2008). Detail Desain Sistem Penyediaan Air Bersih Menggunakan Sumber Mata Air (Studi Kasus: DAS Citarik, Kecamatan Cimanggung, Kabupaten Sumedang). Jurnal Presipitasi, 4(1), 85-91.

20. Nuartha, I., Ghurri, A., \& Priambadi, I. (2016). Analisis Perencanaan Penempatan Pressure Reducing Valve Pada Jaringan Perpipaan Transmisi Air Baku. Jurnal Mettek, 2(2), 68 74.

21. Saparina, W. (2017). Penurunan Kehilangan Air di Sistem Distribusi Air Minum PDAM Kota Malang. Disertasi. Institut Teknologi Sepuluh Nopember.

22. Harahap, Y. M., Bu'ulolo, F., \& Sitepu, H. R. (2013). Faktor-Faktor Yang Mempengaruhi Permintaan Air Minum Pada Perusahaan Daerah Air Minum (Pdam) Tirtanadi Medan. Saintia Matematika, 1(4), 323-336.

23. BPS Kabupaten Cirebon. (2019). Kabupaten Cirebon dalam Angka 2019. Kabupaten Cirebon: BPS Kabupaten Cirebon.

24. PDAM Tirta Jati. (2019d). Daftar Rekening Perbaikan Bulan Juli 2019. Cirebon: PDAM Tirta Jati

25. PDAM Tirta Jati. (2019e). Daftar Sisa Rekening Bulan Juli 2019. Cirebon: PDAM Tirta Jati

26. Hajebi, S., Roshani, E., Cardozo, N., Barrett, S., Clarke, A., \& Clarke, S. (2015). Water distribution network sectorisation using graph theory and many-objective optimisation. Journal of Hydroinformatics, 18(1), 77-95.

27. Utama., T. T., Rachmad A., \& Wasino. (2019). Rencana Induk Sistem Penyediaan Air Minum Kota Tarakan 2019. Tarakan: CV. Artha Gemilang.

28. Roosmini, D., Notodarmojo, S., \& Sururi, M (2018). The characteristic of Natural Organic Matter (NOM) of water from Cikapundung River Pond. IOP Conference Series Earth and Environmental Science, 60(1), pp. 1755 1315.

29. Sururi, M. R., Notodarmojo, S., \& Roosmini, D. (2019). Aquatic Organic Matter Characteristics And THMFP Occurrence In A Tropical River. International Journal, 17(62), 203-211. 